\title{
頭頸部悪性腫瘍患者の免疫学的指標について
}

\author{
田辺均・伊田正道・福田てる代・中島嘉助 \\ 篠崎文彦
}

\section{The immunological parameters in the patient with malignant tumor of head and neck region}

\author{
Hitoshi Tanabe - Masamichi Ida - Teruyo Fukuda \\ Kasuke NAKashima - Fumihiko SHINrzaKi
}

\begin{abstract}
Concerning 23 patients diagnosed as having head and neck region malignant tumor, we studied PPD, PHA, Su-PS skin reaction, and the change of blood lymphocytes subpopulation using the $\mathrm{OK}$ series monoclonal antibody.

Skin reactions showed tendencies of decrease in the following order: good prognostic cases, cancerous cases, and death cases.

In regard to $\mathrm{OKT}-3^{+}, \mathrm{OKT}-4^{+}, \mathrm{OKT}-4^{+} / \mathrm{OKT}-8^{+}$, they showed tendencies of decrease in the following order; good prognostic cases, cancerous cases,and death cases.

We didn't get a significant correlation coefficient from OKT-8 $8^{+}$, OKIal ${ }^{+}$.

The $\mathrm{OKT}-4^{+} / \mathrm{OKT}-8^{+}$decreased in the case of operation, and irradiation therapy.
\end{abstract}

Key words : malignant tumor, skin reaction, OK series

\section{1. は じめに}

担癌生体において，免疫調節機櫣の異常は，その主体 が細胞性免疫であり，中心となっているのが胸腺由来の T-cell であることが知られている1) 現在種々の方法に よる免疫パラメーターの測定がなされており，とくに癌 腫をはじめ, 種々の悪性腫瘍はその発育に伴い細胞性免 疫能が低下寸ることが多くの人たちによって報告されて いる2 わ7) われわれも従来より頭頸部悪性腫瘍患者を中 心に, 細胞性免疫能を調べ, 治療効果の判定や予後の推 測などの目安としている。

今回その一環として PPD, PHA, Su-PS，皮内反応と ともに，ヒトリンパ球サブセットを識別する $\mathrm{OK}$ シリー ズモノクローナル抗体を用いて頭頸部悪性腫㾔患者末梢 血リンパ球の解析を行ったので，その概要を報告する.

山口大学怄学部㳡科口腔外科学教室

（主任：徐崳文彦教授）

Department of Oral and Maxillofacial Surgery, School of Medicine, Yamaguchi University (Chief: Prof. Fumihiko Shinozaki)

受付日・昭和61年 9 月22日
2. 対

象

対象は山口大学医学部付属病院歯科口腔外科を受診 し, 悪性腫痛と診断された22症例で, 病理組織診断で, 扁平上皮癌 22 例, 腺栏整胞癌 1 例であった。

年齢は42 83歳で平均年龄は63.3藏，性別では男性:0 例，女性13例とやや女性に多い傾向がみられた。原発部 位では, 上靧洞 7 例, 歯肉 7 例, 口底 3 例, 舌 2 例, 煩 粘膜 2 例, 下顎骨 2 例で, $\mathrm{T}$ 分類では, $\mathrm{T} 1 ; 1$ 例, T2； 6 例, T3；6例, T4；10例で, Stage 分類では, Stage II ；2 例, Stage III；9例, Stage IV；12例であった。 これら 23 症例をさらに, 一次治療終了後, 臨床的に tumor free の経過良好例 10 例, 現在治療中ならびに再

表 $1 \mathrm{~T}$ 分類および Stage 分類
$\mathrm{T}$ 分類

T1：2例

T2: 6例

T3 : 5 例

$\mathrm{T} 4: 10$ 例
Stage 分類

Stage I : -

Stage II : 2例

Stage III $: 10$ 例

Stage IV : 11例 
表 2 経過良好例 : 10例

\begin{tabular}{|c|c|c|c|c|c|c|c|}
\hline 氏 & 名 & 年䊀 & 性別 & 原発部位 & TNM 分類 & Stage 分類 & 療 \\
\hline 1. & & 56 & 우 & 下顎歯肉 & T1N1M0 & III & 化, 手 \\
\hline 2. & & 56 & $\hat{0}$ & 下㴿荬肉 & T2N1M0 & III & 化, 手 \\
\hline 3. & & 73 & 우 & 下顎终肉 & $\mathrm{T} 4 \mathrm{~N} 1 \mathrm{M} 0$ & IV & 化, 手 \\
\hline 4. & & 74 & 우 & 上顎㴹肉 & T2N0M0 & II & 化, 手, 放 \\
\hline 5. & & 78 & 우 & 下顎檤肉 & $\mathrm{T} 2 \mathrm{~N} 1 \mathrm{M} 0$ & III & 化, 手, 放 \\
\hline 6. & & 64 & 우 & 口底 & T3N0M0 & III & 化, 手, 故 \\
\hline 7. & & 72 & 우 & 口底 & T3N1M0 & III & 化, 手 \\
\hline 8. & & 48 & 우 & 舌 & $\mathrm{T} 2 \mathrm{~N} 1 \mathrm{M} 0$ & III & 化, 手 \\
\hline 9. & & 61 & 우 & 上顎洞 & T3N0M0 & II & 化, 手, 放 \\
\hline 10. & & 45 & $\uparrow$ & 煩粘膜 & T3N1M0 & $\mathbb{I I}$ & 化, 手 \\
\hline
\end{tabular}

表 3 担癌例 : 9 例

\begin{tabular}{|c|c|c|c|c|c|c|c|}
\hline 氏 & 名 & 年齢 & 性別 & 原発部位 & $\mathrm{TNM}$ 分類 & Stage 分類 & 法 \\
\hline 1. & & 42 & 우 & 上顎洞 & $\mathrm{T} 4 \mathrm{~N} 2 \mathrm{M} 1$ & IV & 化** \\
\hline 2. & & 75 & 우 & 上顎洞 & T3N2M1 & IV & 化, 手, 放 \\
\hline 3. & & 83 & 우 & 上顎洞 & T4N1M0 & IV & 化, 放 \\
\hline 4. & & 51 & 今 & 下顎骨 & $\mathrm{T} 4 \mathrm{~N} 1 \mathrm{M} 0$ & IV & 化, 放 \\
\hline 5. & & 64 & 우 & 下買骨 & T4N1M0 & IV & 化, 手, 放 \\
\hline 6. & & 65 & 今 & 下顎檤肉 & $\mathrm{T} 4 \mathrm{~N} 2 \mathrm{M} 0$ & IV & 化, 手, 放 \\
\hline 7. & & 70 & $\hat{\sigma}$ & 下顎歯肉 & T2N0M0 & II & 化, 手, 放 \\
\hline 8. & & 55 & 今 & 口底 & T4N1M0 & IV & 化, 手, 放 \\
\hline 9. & & 69 & 우 & 舌 & T1N1M0 & $\mathbb{I I}$ & 化, 手, 放 \\
\hline
\end{tabular}

** Adenoid cystic carcinoma

表 4 死亡例 : 4 例

\begin{tabular}{|c|c|c|c|c|c|c|c|}
\hline 氏 & 名 & 年齢 & 性別 & 原発部位 & $\mathrm{TNM}$ 分類 & Stage 分類 & 法 \\
\hline 1. & & 50 & 今 & 上顎洞 & $\mathrm{T} 4 \mathrm{~N} 2 \mathrm{M} 0$ & IV & 化, 手, 放 \\
\hline 2. & & 56 & $\hat{\delta}$ & 上顎洞 & $\mathrm{T} 4 \mathrm{~N} 1 \mathrm{M} 0$ & IV & 化, 放 \\
\hline 3. & & 72 & 今 & 上顎洞 & $\mathrm{T} 4 \mathrm{~N} 1 \mathrm{M} 0$ & IV & \\
\hline 4. & & 75 & 今 & 煩粘膜 & $\mathrm{T} 2 \mathrm{~N} 1 \mathrm{M} 0$ & III & 化, 手. 放 \\
\hline
\end{tabular}

発を認めた担癌例 9 例, 悪性腫瘍を原因とした死亡例 4 例について検索を行った（表1）.

経過良好例10例では，年齢は45～74歳，平均年路 62.7 歳, 原発部位は雪肉 5 例, 口底 2 例, 上顎洞 1 例, 煩粘 膜 1 例, 舌 1 例. Stage 分類では Stage II ； 1 例, Stage III；8例, Stage IV；1例であった（表 2).

担癌例 9 例では, 年龄 $42 \sim 83$ 祡, 平均年齢63.8歳, 原 発部位は上顎洞； 3 例, 下顎骨 ; 2 例, 歯肉；2 例, 口 底； 1 例, 舌； 1 例. Stage 分類では Stage II ; 1 例, Stage IV；8例であった（表 3).

死亡例 4 例はいずれも 男性で，50〜75 歳，平均年齢
63. 3 歳，原発部位は，上䫈洞 3 例，頓粘膜 1 例で, Stage 分類では, Stage II ；1 例, Stage IV；3 例であった(表 4 ).

\section{3. 免疫能の検査法}

\section{1）皮内反応}

PPD 皮内反応には，一般診断用精製ツベルクリン液 $(0.5 \mu \mathrm{g} / \mathrm{m} l$, 日本 $\mathrm{BCG}$ 社製) $0.1 \mathrm{~m} l$ 用い 48 時間後 に判定した。

PHA 皮内反応には purified PHA $5 \mu \mathrm{g} / 0.1 \mathrm{ml}$ (中外 

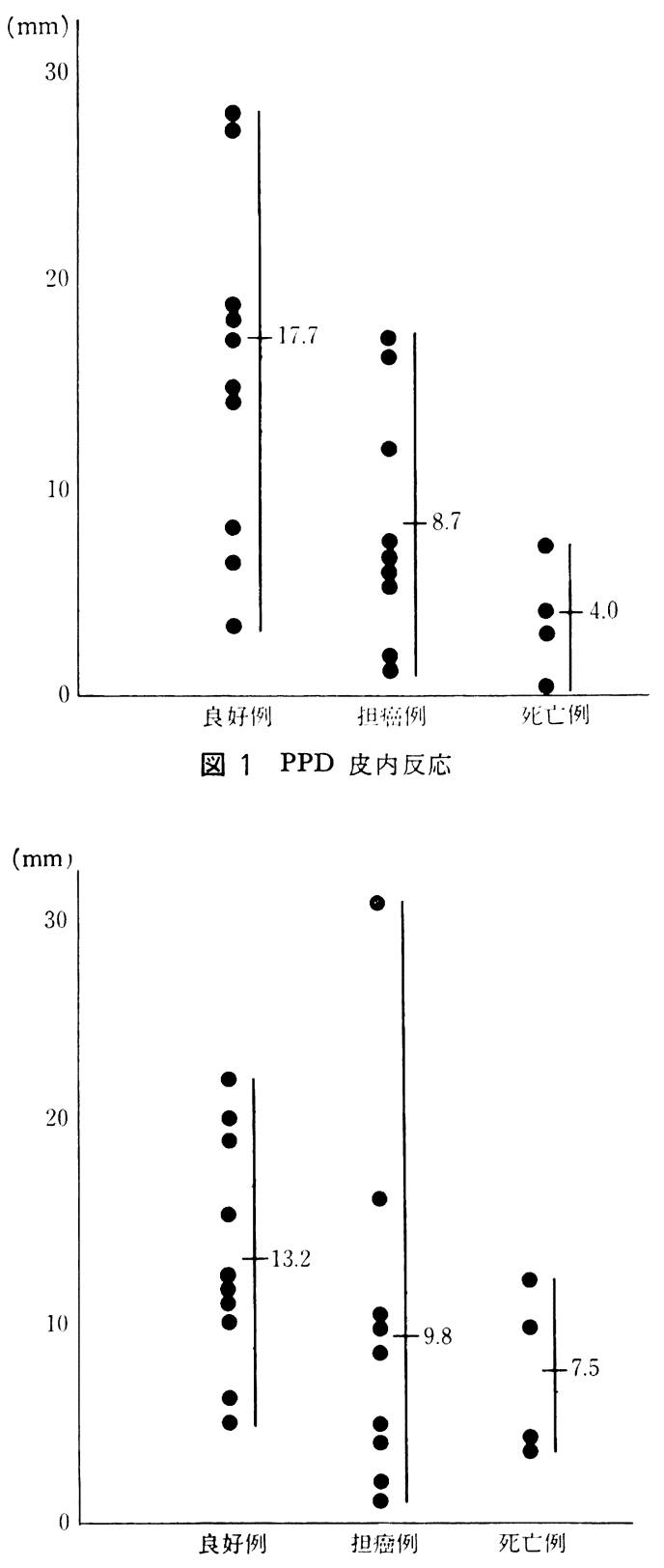

図 2 PHA 皮内反応

製薬製）を用い24時間後に判定した.

$\mathrm{Su}-\mathrm{PS}$ 皮内反応には, 溶連菌 Su 株より抽出したポリ サッカライド $20 \mu \mathrm{g} / 0.1 \mathrm{ml}$ (中外製楽製) を用い24時間 後に判定した.

皮内反応の判定は, 発赤斑の長径と短径の和の skin reaction としてプロットした。 なお，陽性判定は PPD， PHA, Su-PS すべて $10 \mathrm{~mm}$ 以上とした.

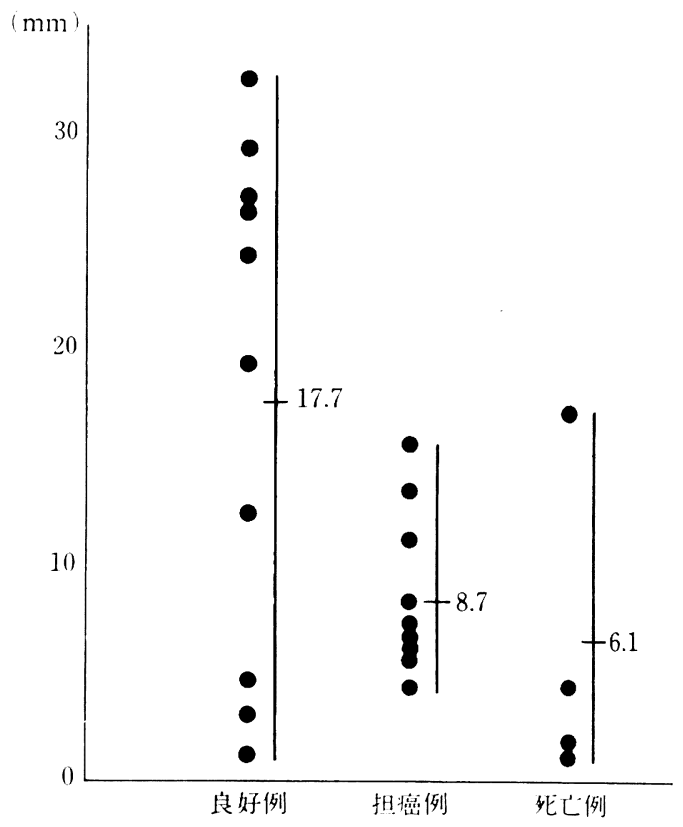

図 $3 \mathrm{Su}-\mathrm{PS}$ 皮内反応

表 5 各種皮内反応の陽性率

\begin{tabular}{c|c|c|c}
\hline & 良好例 & 担癌例 & 死亡例 \\
\hline \multirow{2}{*}{ PPD } & $70 \%$ & $33 \%$ & $25 \%$ \\
& $(7 / 10)$ & $(3 / 9)$ & $(1 / 4)$ \\
PHA & $70 \%$ & $33 \%$ & $25 \%$ \\
& $(7 / 10)$ & $(3 / 9)$ & $(1 / 4)$ \\
Su-PS & $70 \%$ & $33 \%$ & $0 \%$ \\
& $(7 / 10)$ & $(3 / 9)$ & $(0 / 4)$ \\
\hline
\end{tabular}

2）リンパ球モノクローナル抗体について

モノクローナル抗体による末梢血リンパ球サブセット については，へパリン加末梢血 $2 \mathrm{~m} l$ を採取の後, Ficol 法にてリンパ球を分離し, FITC 標識モノクローナル抗 体 (オーソ社製) OK シリーズ (OKT-3, OKT-4, OKT-8, OKIa 1) を用い細胞解析は flow cytometry にて行った.

症例によって治療実日数, 治療法, 測定回数が異なっ ているため, 今回は最近の測定回数 3 回以上 6 回までの 平均值をプロットした。

\section{4. 結果}

\section{1）皮内反応について}

PPD 皮内反応については, 経過良好例 10 例の平均値 $17.7 \mathrm{~mm}$, 担癌例 9 例の平均值 $8.7 \mathrm{~mm}$, 死亡例 4 例の 平均值 $6.1 \mathrm{~mm}$ と病態の進行とともに低下傾向を認め 


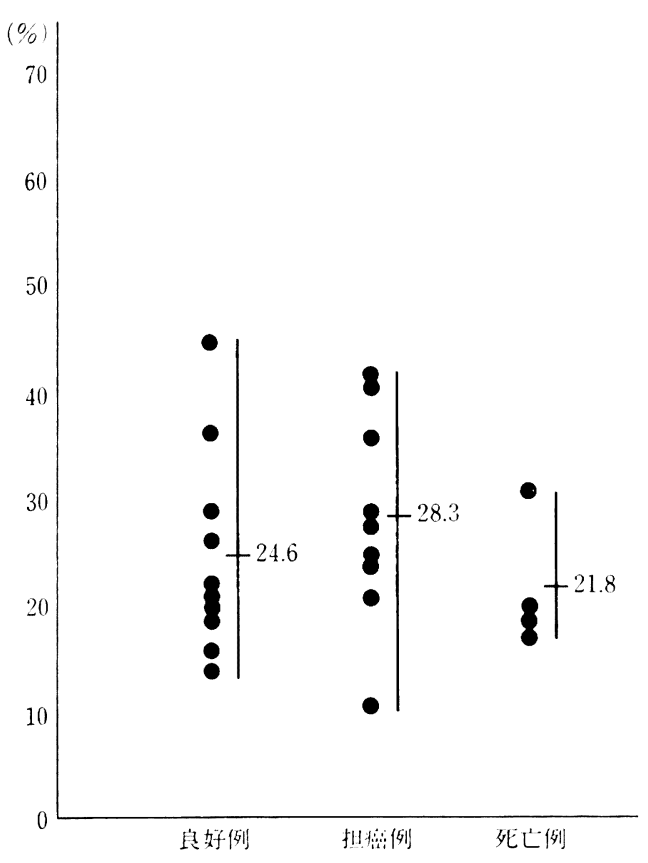

図 4 各症例に打壮 OKIa 1 陽性細胞のしめる 制合

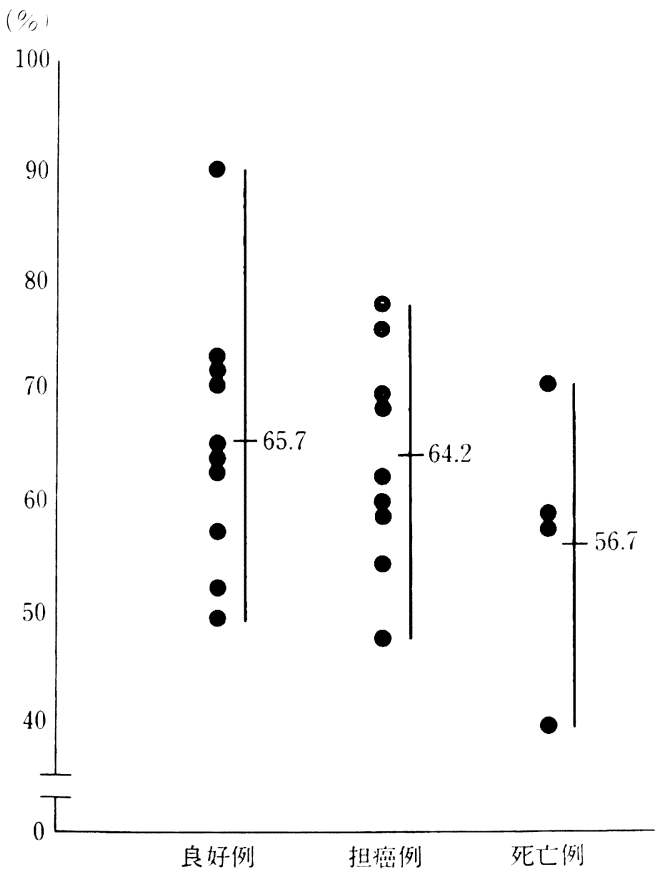

図 5 各症例に扣ける OKT-3 陽性細胞のしめる割 合

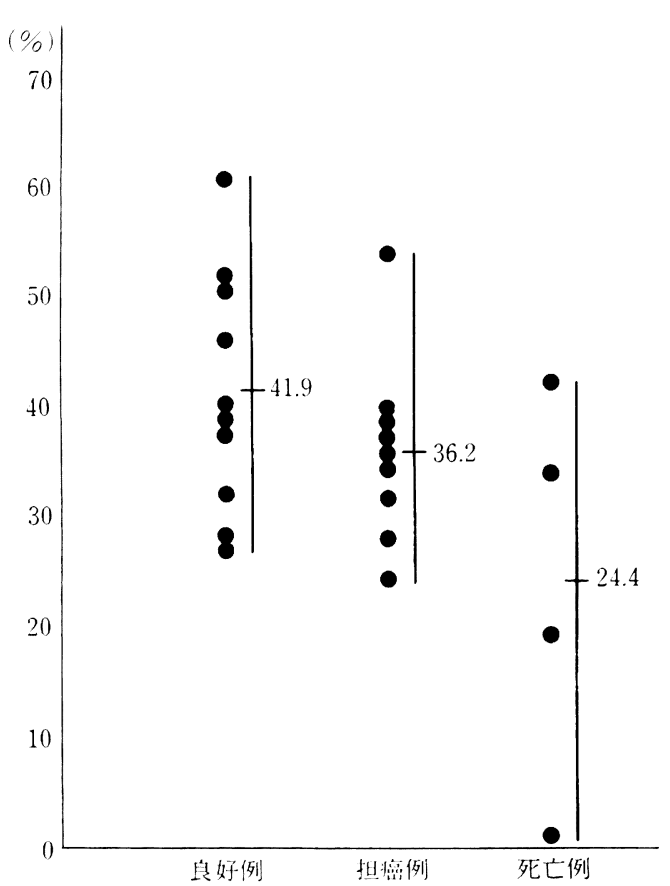

図 6 各症例にお汁る OKT-4 陽性細胞のしめる割 合

た（図1)。

PHA 皮内反応でも経過良好例 $13.2 \mathrm{~mm}$, 担癌例 9.8 $\mathrm{mm}$, 死亡例 $6.1 \mathrm{~mm}$ と同様の傾向を認めた（図 2).

Su-PS 皮内及応でも同様に経過良好例 $17.7 \mathrm{~mm}$ ，担 癌例 $8.7 \mathrm{~mm}$, 死亡例 $4.0 \mathrm{~mm}$ と病態の進行に従って負 の相関関係を示した（図3）.

各種皮内反応の陽性率を比較検討すると，経過良好例 では，PPD，PHA，Su-PS，各70\%，担癌例は各 33\%， 死亡例では PPD, PHA は25\%, Su-PS は全て陰性で あった（表 5 ).

2）ひとリンパ球モノクローナル抗体の検索

OKIa 1 ; B リンハ球, 単球, 活性化 Tリンパ球につ いては経過良好例，担癌例，死亡例ではその経過で著明 な変動はみられなかった（図４）。

OKT-3; T リンパ球については，経過良好例 10 例の 平均値 $65.7 \%$, 担癌例 9 例の平均值 $64.2 \%$, 死亡例 4 例 の平均值 $56.7 \%$ とわずかながら病態の進行とともに低下 傾向を示した（図 5 ).

OKT-4; helper inducer T-cell については経過良好 例, 担癌例, 死亡例の順にその 平均值は $41.9 \%, 36.2$ $\%, 24.4 \%$ と低下傾向を示した（図 6).

OKT-8 ; suppressor cytotoxic T-cell については, ほ とんどの症例で著明な変動はみられなかった。平均が 28.4 (良好例), $33.0 \%$ (担癌例), $26.0 \%$ (死亡例) で 


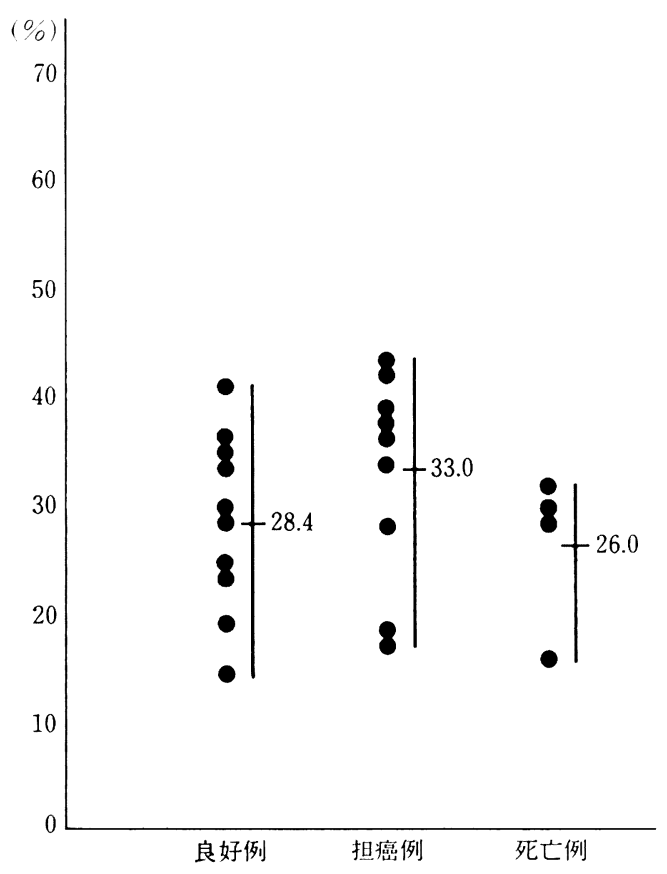

図 7 各症例に扣ける OKT-8 陽性細胞のしぬる割 合

大差は見られず，担癌例が若干高い傾向を示した（図 7 ).

免疫調節機能を最もよく表し, 担癌生体では低下が見 られるといわれている OKT $-4^{+} / \mathrm{OKT}-8^{+}$は，良好例 1.7 , 担癌例 1.3 , 死亡例 1.2 の順にその平均值は低下し 病状を比較的よく反映していた（図8）.

また，手術と放射線治療の影響について 9 症例の， OKT $-4^{+} / \mathrm{OKT}-8^{+}$の変動を検索した結果, 術後あるい は放射線療法後（ $2 \sim 3$ 週後）は全症例が低下していた が，1 か月半〜 2 か月後には 9 症例全部がほぼ治療前の 状態に復していた (図 9).

\section{5. 考察}

近年, 担癌生体において, その臨床経過と細胞性免疫 能との間には相関性があるいわれている ${ }^{11}$. 細胞性免 疫能の状態を把握することにより予後を推定することも 可能であり, 免疫パラメーターの動態が有力な手がかり になることがしられている( 6). 現在多くの免疫学的機 能検査が行われているが2 7), 測定手技の繁雑なことや, 機器が高価なこともありすべての検査がどこの施設でも できるというわけではない，その中で PPD, PHA, SuPS 等の皮内反応は比較的簡単で, しかも病態をある程

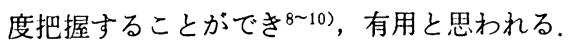

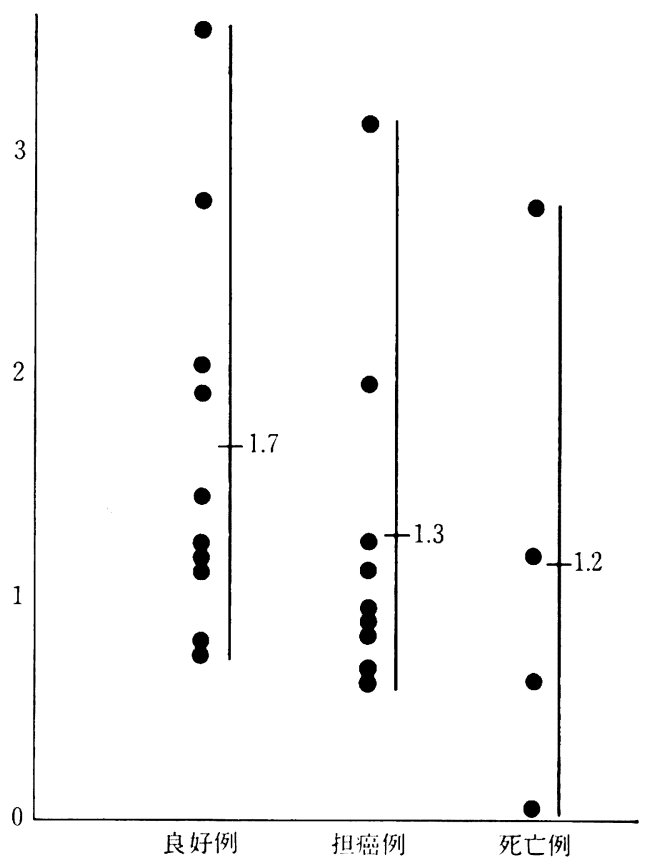

図 8 各症例に拈ける OKT-4 陽性勫胞と OKT-8 陽性細胞の比率

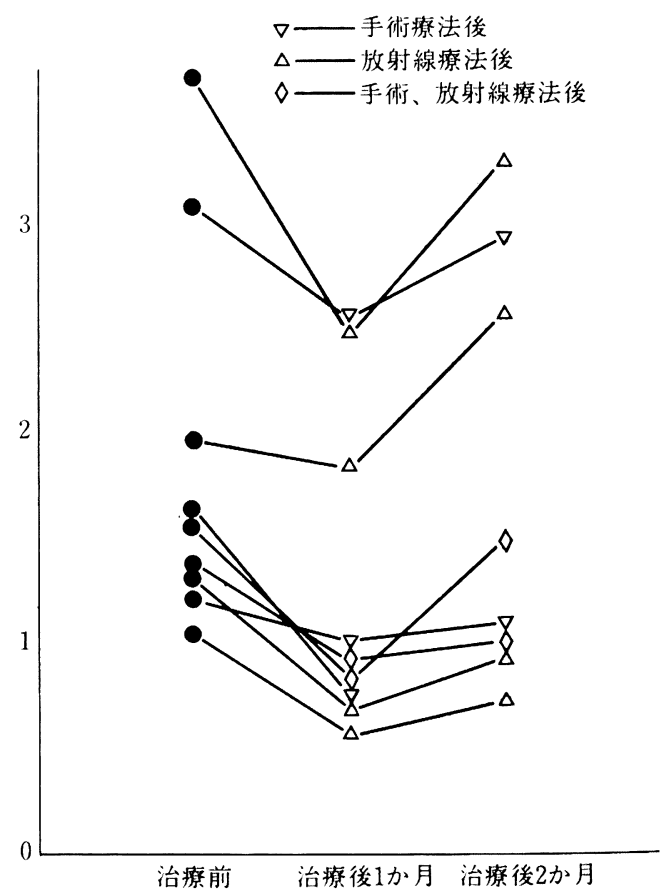

图 9 OKT-4 陽性科胞と OKT-8 陽性紐胞の比 率の推移 
PPD は結核菌を培養した 合成培地からトリクロル酢 酸で沈股させて調製した可溶性タンパク質で，結核菌に よる感作または感染に対する診断試薬として用いられて きた。しかし，担癌生体においては陽性率が低下し，各 種癌治療や免疫療法により陽転する例が見られること や，他の免疫学的パラメーターとよく相関する10)ことな とにより多くの施設で利用されている。

PHA はウズラマメの種子から抽出したタンパクで T-cell の強力な mitogen であるが, PPD, Su-PS と違 って感作，感染の有無に対する心配がなく，病態の進行 に従って陽性率が低下するといわれている

Su-PS は Streptococcus pyogenes A 群吕型 Su株を 培養後トリクロル酻酸にて抽出したポリサッカライド で，PPD 皮内反応同様に recall antigen による遅延型 皮膚反応を起こす。 Su-PS は健康人では大部分陽性を 呈すが，進行癌患者では反応の低下がみられ，また OK432 による免疫療法においてその臨床効果をよく反映し ているといわれる11,12)

今回われわれの検索した各種皮内反応は，いずれも良 好例, 担癌例, 死亡例の順に低下傾向を示し, 陽性率さ 良好例では $70 \%$ ，担癌例 $33 \%$ ，死亡例では PPD，PHA 各 $25 \%, \mathrm{Su}-\mathrm{PS} 0 \%$ と低下傾向を示している。しかし $\mathrm{Su}-\mathrm{PS}$ は，前述のように recall antigen であり，OK432 によく反映するが，全症例に OK-432 投与を施行し ているわけでなく幾分問題点が残る。けれども，いずれ にしても各皮内反応は病態の進行とよく相関しているよ らに思われた。

1975年, Kohler と Milstein ${ }^{13)}$ はマウス骨髄腫の細胞 とある抗原 Xで感作されたマウスの脾臓細胞を融合さ せ，そのある抗原Xに対する抗体だけを無限に造り続け る培歪細胞を得ることに成功し，単クローン性抗体産生 の技法を確立した，以来種々のモノクローナル抗体が開 発されるよ5になり，各種自己免疫疾患をはじめ多くの 疾患の解析 ${ }^{14)}$ に役立っている。

細胞性免疫の主体をなす Tリンパ球の細胞膜抗原を認 識するモノクローナル抗体には, OK シリーズ, Leu シ リーズ，Tシリーズなど7をはじめいくつかの方法があ り細胞性免疫能の検索が可能になってきた。

今回われわれが $\mathrm{OK}$ シリーズ・モノクローナル抗体を 用いて検索した限りでは, OKIa 1 ; B リンパ球, 単球, 活性化 Tリンパ球については経過良好例，担癌例，死亡 例では特異的な変動は見られなかったが， OKT-3；T リンパ球では, 病態の進行に従ってわずかではあるが低 下傾向が見られた。 また OKT-4; helper-inducer T細 胞は，経過良好例，担癌例，死亡例の順に低下傾向を示 し，OKT-8 ; suppressor-cytotoxic $\mathrm{T}$ 細胞は病態との相 関は得られなかったが，OKT-4 陽性細胞と OKT-8 陽 性細胞とは互いに相補的関係にあり， OKT-4 陽性細胞 は少数で helper 活性を示すが，その数が多くなるとか
えって helper 活性が悪くなるといわれ15)ており，OKT一 $4^{+} / \mathrm{OKT}-8^{+}$は 1.5 前後の值が健常者の平均值とされて いる。われわれが検索した限りでも，経過良好例; 1.7 , 担癌例 ; 1.3, 死亡例 ; 1.2 と病態の進行順に低下を認 めるが，これは OKT-4 陽性細胞の低下によるものが大 きいと考えられる。

$\mathrm{OKT}-4^{+} / \mathrm{OKT}-8^{+}$は，その細胞性免度能をよく反映 して拈り，手術，放射線療法など全身的なダィージを受 けるような治療において低値を示すといわれている19). われわれも 9 症例について, 放射線療法, 手術療法前之 療法後における比較を行ったところ，すべての症例で一 過性の低下を認め, 全身状態の回復に伴って治療法前の 值に戻る傾向を示した。しかし，OKT $-4^{+}$細胞は放射 線照射により helper 機能が失われるともいわれてお り ${ }^{15)}$ ，放射線療法を行った患者では， helper/suppressor は実際の数値よりもさらに低い值を示すのではないかと 考えられる。

現在，リンパ球サブセット測定に関しても数多くのモ ノクローナル抗体が開発されており, 細胞性免疫能の低 下を明らかにするのに helper, suppressor たけでなく killar, natural killer $\mathrm{T}$ 細胞も测定可能となってきてお り種々の疾患の解明に応用されつつある。われわれの領 域でも口腔の癌腫や，喠液腺にみられる悪性リンパ腫な と種々の疾患について検索がなされており，治療法や予 後を推定するのになくてはならぬ検査の一つになりつつ ある。また NK 細胞については癌腫の転移形成に対して 抑制的な働きを示すなどの報告 ${ }^{20)} も あ り ， 今$ 後の検討の 課題とされるところである。

\section{6. ま と め}

1. 頭頸部悪性腫瘍患者と診断された 23 例（経過良好 例10例, 担癌例 9 例, 死亡例 4 例) について, PPD, PHA，Su-PS 皮内反応と末梢血リンパ球サブセットの 変動を $\mathrm{OK}$ シリーズモノクローナル抗体を用いて検索し た。

2. 各皮内反応は良好例, 担癌例, 死亡例の順に低下 傾向を示した。

3. OKT-3, OKT-4, OKT-4/OKT 8 については, 良好例, 担癌例, 死亡例の順に低下傾向を示した。

4. OKT-8，OKIa 1 については，著明な相関関係は 得られなかった。

5. 手術と放射線治療により OKT-4/OKT-8の一過 性の低下を認めた

本論文の要旨は, 第30回日本口膑外科学会総会(1985 年，9月24日，25日 東京）に拈いて発表した。 


\section{引用 文 献}

1）藤林孝司：口腔癌における稩胞性免疫反応に関 する研究。口科誌 32：657-695 1983.

2) Hughes, L.E. and MacKay, W.D.: Suppression of the tubuerculin response in malignant disease. Br Med J 4: 1346-1348 1965.

3) Eilber, F.R., Morton, D.L., et al.: Immunologic abnormalities in head and neck cancer. Am J Surg 128: 534-538 1974.

4）瀬山疸：顎・口腔領域癌腫患者の細胞性免疫 能に関する研究. 第 1 編 末梢リンハ球の幼若 化能と初診時病態との関係. 広大料誌 14：1561661982

5）折田黄三, 三輪努昭，他：リンパ球芽球化現象 から，癌の臨床 24：941-947 1978.

6）黑川英雄, 暒山稔, 他 - 顎 - 口腔領域に打け る悪性腫瘍患者の稩胞性免疫反応に関する検討 一PPD 皮内反応について一。 口科誌 33：5635731985 .

7) 水越正信, 田沢裕光, 他：モノクロナール抗体 によるリンパ球サブセット・フローサイトメト リ一全血測定法の検討。臨床病理 32：809-813 1984.

8）花上仁, 野本信之助, 他：瘤免疫療法に打汁 る免疫学的ハラメータ一と予後について，日消 外会誌 16：1374-1379 1983.

9）亀井秀雄：各種パラメーターの相関性。癌の臨 床. 24：949-955 1978.

10) Nicholls, E.M.: Aggregation of buffy coat leucocytes-a simple, sensitive assay for cellmediated immunity. Clin Exp Immunol 17:
673-680 1974

11）渡辺洋宇, 山田哲司, 他: OK-432による免疫 療法に際しての SUーポリサッカライド皮有反 応の意義。癌と化学療法 8：1068-1083 1981.

12）小谷 勝, 能谷茂宏: 口腔癌患者に対する㭪後 OK-432 療法と Su-PS 皮内反応の推移. 診療 と新薬 21：416-421 1984.

13) Kohler, G. and Milstein, C.: Continuous cultures of fused cells secreting antibody of predefined specificity. Nature 256: 495-497 1975.

14）矢田純一：モノクローナル抗体によって同定さ れる丁細胞亜群とその疾患における変動。臨休 免疫 13：891-899 1981.

15) Thomas, Y., Sosman, J., et al.: Functional analysis of human $T$ cell subsets defined by monoclonal antibodies. I) Collaborative $\mathrm{T}-\mathrm{T}$ interactions in the immunoregulation of B cell differentiation. J Immunology 125: 2402-2408 1980.

16) Bach, M. and Bach, J.: Imbalance in T cell subsets in human diseases. Int J Immunophamac 3: 269-273 1981.

17）諸山隆生, 遠藤邦彦, 他 : 顎・口腔領域扁平上 皮瘦患者の末梢血リンパ球サブセットの変動。 癌の臨床 31: 117-121 1985.

18）林良夫, 佐藤光信, 他 : 頭頸部癌患者末梢り ンハ球サブセットの異常一単クローン抗体によ る解析一。医学のあゆみ 128: 507-508 1984.

19）領家和男，森田ますみ，他：口腔癌患者の末梢 血リンパ球サブセットの検討。口科誌(会) 33: 8191985.

20) 内田温士, 星野孝, 他：NK 細胞と癌. Oncologia 6: 33-42 1983 